by a 'wider range of animals than any other hero'; there is the lion when he meets Nausicaa, the octopus when he is clinging to a rock before he makes landfall at Scherie and a bat when he is clinging to the fig tree in book 12; of these the lion is a relatively common comparator, but the latter two are most inventive and typical of the Homeric poet. Understandably the journey to the Underworld (nekyia) is a chosen theme to explore and explain Odysseus' character and motivation to return home to Ithaca and to cheat death in the process. Overall, this is an excellent resource and accessible to students, though the sections on the epics themselves would be best read after the text has been studied.

doi:10.1017/S2058631020000574

\section{Not all Dead White Men. Classics and Misogyny in the Digital Age.}

\author{
Zuckerberg (D.). Pp.270. Cambridge, MA: \\ Harvard University Press, 2018. Cased, £22.99, \\ US\$27.95, €25 (Paper, £13.95, US\$16.95, €15.15). \\ ISBN: 978-0-674-97555-2.
}

Jo Lashly

Shrewsbury High School.

\section{NOT ALL DEAD WHITE MEN

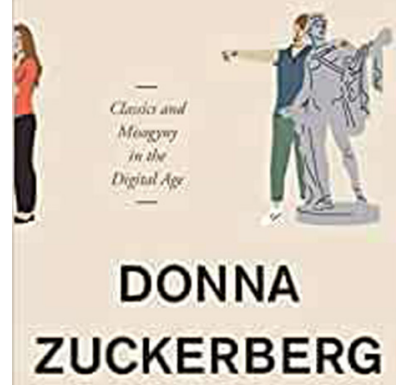

I found this quite a difficult book to read; not because of its complexity, though in a way it was, but because of the sometimes difficult subject matter. It is an interesting book and very apt for its time, coming, as it does, in the age of Trump, The Handmaid's Tale and Black Lives Matter, but there are so many acronyms to cope with and an overwhelming feeling of the desperate inadequacy felt by the major players in the 'manosphere'. While I was reading it, the Republican National Conference was being reported from the States, 'Mrs America' was being advertised on UK television and there were reports of women calling for one-vote households where the man of the house had the final say, 'if it were a godly household. The premise of the book is that the Alt-Right, the TRP (The Red Pill, named for the choice between red and blue pills in The Matrix) and sundry other groups that seem to be united by a resentment against women, people of colour and the liberal élite, have hijacked (and misrepresented in part) classical literature to give a gravitas to their ideas. The author, Donna Zuckerberg, younger sister of Facebook founder, Mark Zuckerberg, is a classicist and well-read in the literature that she discusses. She is also not blind to the societal norms of the ancient world that kept women more closeted than is the case for western societies these days; but it is a USA-centric approach (that is not to say that there are not elements of it in other western societies but it seems to be less desperate). The alacrity with which these groups focus on classical texts, particularly Stoic philosophy and Greek tragedies such as Hippolytus, is understandable in some respects; but it is also typical of a society which was heavily based on classical constructs - see their political architecture, the naming of the Senate and the latifundia plantations of 100 years ago that were tended by slaves (though other western societies were not blameless in this respect). Zuckerberg explains how Stoicism in particular reinforces the belief that men are guided by rationality and women by emotion which means that women should be ruled by men. She also explains how a reading that stops at this point is missing the point that women too could aspire to true virtue though with the gendered language of the ancient world (virilis, àv $\delta \rho \varepsilon \tilde{\alpha}$ ). Whilst the chapter on Stoicism was interesting, it would be the chapter on Ovid that, I think, would draw in more people. This chapter focuses on the use by the 'manosphere' of Ovid's Ars Amatoria as a handbook not only on seduction but on how to treat women generally. Whilst there are parts of this work which are not very savoury (and indeed there are elements of the Amores (the behaviour of the narrator in III.2 perhaps?) too with which we might take issue), Zuckerberg does acknowledge that this is a work of literary fiction and probably not to be taken literally; and the resentment of the members of the 'manosphere' is apparent particularly in the section on Danish women who, it seems are immune to Ovidian seduction techniques as they have 'no idea what it feels like to not have medical care or free access to university education. They have no fear of becoming homeless or permanently jobless. The government's soothing hand will catch everyone as they fall'. So, it seems that women are only prey when they are likely to be vulnerable, which rather reinforces the idea that many of those in these groups are inadequate. Sadly, the use and abuse of Classics is not restricted to The Alt-Right and the The Red Pill group: there are numerous examples amongst some UK politicians of Latin (and Greek) tags and references being dropped into speeches or interviews, perhaps to advertise an élite education and to sound clever. This does Classics no good and is unfair on those who work so hard to bring it to a wide range of people, especially those who are encouraged to exert their critical faculties on it, as should be done with all subjects. No civilisation can be perfect, but the faults and beauties should be seen for what they are and not highjacked for political or societally sinister motives. This is an interesting book, but one which I cannot see being widely read in schools. In times of financial probity, it might be a luxury. I am glad I read it, though there are some views that I would hope never to encounter. Still, forewarned is forearmed, and a knowledge of how some of these groups work is a useful tool.

doi:10.1017/S205863102000063X

\section{Aristotle: Poetics}

Zerba (M.), Gorman (D.) (edd., revised trans.). Pp. xxxviii + 209. New York \& London: W. W Norton and Company, 2018. Paper, £7.95. ISBN:

978-0-393-93886-9.

\section{Maria Bergquist}

Merchant Taylors' School, Northwood

Aristotle's Poetics is perhaps the most influential work of literary theory. As such, it enjoys a wider audience than some of Aristotle's other works. This edition, with its introduction, glossary, notes on 